\title{
A Post-Traumatic Growth Of The Jemaat Ahmadiyah In Indonesia: The Effect Of Positive Religious Coping, Resiliency And Social Support
}

\author{
Intan Hanifatunisa ${ }^{1}$, Achmad Syahid ${ }^{2}$ \\ intanhanifatunisa@gmail.com ${ }^{1}$, achmad_syahid@uinjkt.ac.id ${ }^{2}$ \\ 12Psychology Faculty of UIN Syarif Hidayatullah Jakarta, Kertamukti Street, no 5, Cirendeu, \\ Tangerang Selatan, Banten
}

\begin{abstract}
This article discus the effect of positive religious coping, resilience and social support on posttraumatic growth of Jemaat Ahmadiyya. A sample of 200 Jemaat Ahmadiyya victims of the 2005 attack in Cianjur taken with non-probability sampling techniques. Author modify the measuring instrument that consists of Post Traumatic Growth Inventory (PTGI), Religious Coping Measures (RCOPE), International Resilience Research Project (IRRP), Berlin Social Support Scale (BSSS). Validity of measuring instruments using techniques confirmatory factor analysis (CFA). Data analysis using multiple regression analysis techniques The results showed that there was significant effect of positive religious coping, resilience and social support on posttraumatic growth in Jemaat Ahmadiyya victims. The test result minor hypothesis that examine the effect on posttraumatic growth. Only six regression coefficients that significantly influence posttraumatic growth, namely: intimacy, external supports (i have), inner strength (i am), perceived emotional support, perceived instrumental seeking support and support seeking. Based on all variant proportions, post-traumatic growth (PTG) are influenced by the independent variables of $60.2 \%$. The author hopes that the implications of the results of this study can be reviewed and development in future studies. In addition, it is necessary to pay attention to the selected measuring instruments in the measurement of variables.
\end{abstract}

Keywords: The Posttraumatic growth, Ahmadiyya, positive religious coping, resilience, social support

\section{Introduction}

Competitiveness, independence, self- development and adaptability are important indications and markers of the 21 st century as a healthy personality. Allport [1], Rogers [2], Maslow [3] and Frankl [4] emphasized that a healthy person is characterized by a desire to grow and develop, future-oriented while remaining realistic and able to innovate for himself and his environment. Edwards et.al, [5] mentions that healthy people do not like those who experience mental health problems or called Halgin [6] suffering from abnormalities, goodness always radiates from them, freedom to express themselves, feelings and thoughts. 
Daradjat [7] and Hamid [8] mention that mental health is an essential so that a person is able to adjust to his environment, able to develop his potential as fully as possible in order to reach the pleasure of Allah SWT, and by developing all aspects of intelligence, both spiritual, emotional, and intellectual health. Health is a state of well- being of the body, soul and social that enables everyone to live productively socially and economically. In the 21 st century, Wilber et. al., [10] mentions that a person must live complementarily, between a healthy physical body, emotional harmony, a clear mentality and a spirit that is full of consciousness. Religion and culture can be a reservation for one's mental health [11].

Psychology and mental health of a person can be disrupted by natural disasters [12], terrorism [13], colonialism [14], physical and mentalThis Word document can be used as a template for journal. This Word document can be used as a template for journal. violence and anxiety disorders [15], and negative events, such as mourning, fighting, war, refugees and others [16],[17]. Jemaat Ahmadiyya, according to LBH Jakarta Indonesia records, experienced 32 cases of physical and mental violence, as well as discriminatory treatment between 20012011. The jemaat Ahmadiyya often experiences physical and mental violence. Even human rights violations such as the prohibition of worship in accordance with their beliefs. Chronic violence and discrimination occur in various regions of Indonesia such as Pekan Baru, West Lombok, Makassar, Surabaya, Cikeusik (Pandeglang), Cianjur, Ciamis, Garut, Tasikmalaya, Sukabumi, Bogor, Ciputat, Tanjung Priok etc. The most monumental was the invasion of thousands of people of the Indonesian Islamic Community Movement (GUII) on Friday, July 15, 2005, demanding the dissolution of the Secretariat of the Jemaat Ahmadiyah.

Verbally, Basit [18] and Bonasir (2018) said that they were denounced as deviant groups, considered infidels [18],[19]. Dodi [20] said that the various physical and mental violence caused psychological problems such as the trauma of hearing the sounds of mass screaming, the roar of motorbikes and the sound of broken glass because it was thrown at stones; long stress such as trembling and tense; anxious and sad, and haunted by prolonged traumatic events. Impaired mental health also causes anti-social behaviour [21]. Violence against the jemaat Ahmadiyya also makes victims tend to withdraw from the social environment so that it becomes closed, not daring to reveal their true identity, for fear of being called heretics. Because it is more vulnerable than men, Indonesia's National Commission for Women and Children (Komnas PA) states that the violence has a prolonged impact on women. Shinta Nuriyah Wahid [22] said the mothers who were victims of violence experienced psychological trauma, worries about children's development and education, disrupted family relationships and fear during worship.

As a victims, the jemaat Ahmadiyya experienced what Goulston (2007) called posttraumatic stress disorder (PTSD) [23]. Usually PTSD is a disorder for humans for a long time. Stocker (2010) mentions many different causes of PTSD, besides physical violence, domestic violence, vulnerability to sexual violence and incest, war, and children who feel neglected, etc [24]. The signs of PTSD in the jemaat Ahmadiyya are not being able to sleep soundly because of the fear that there will be a follow- up attack, deep sadness for the family members who are killed, the appearance of fear when hearing, seeing, smelling or feeling something similar to when the incident took place. The impact of traumatic events that cause depression that damage the psychological-mental and quality of life. Rahmah's 
research (2017) proves that victims of the Aceh conflict experienced PTSD, as if they felt they heard gunshots that killed their family members [25].

With family involvement [26], both PTSD and related traumas can be diagnosed, managed, intervened and cured by counseling [27] and therapy to further their potential [28]. Rahmah's (2017) found that after the victim went through a post-crisis crisis that he experienced there were aspects of him experiencing change and improvement: more respect for life, his personality changed to be stronger, inclined to spiritual and open insight into new possibilities [25]. Thabet (2017) mentions posttraumatic growth (PTG) refers to changes in someone who has the ability to fight and not give up with a very tense situation [29]. Tedeschi and Calhoun (2004) and Morrill et. al., (2008) explains that PTG is the experience of positive changes as a result of the struggle after experiencing a traumatic event. The process of arising from a traumatic event for the jemaat Ahmadiyya is a sign of PTG [30]. They are more steadfast and patient, sincere, not vindictive, feel more confident in the truth of his understanding, gain many gifts and wisdom of God for spiritual and physical progress.

Laufer \& Solomon [31] mention religiosity is an important predictor of PTG Religious youth have higher PTG levels compared to secular youth. Religious commitment and participation in religious activities are positively correlated to PTG [32]. Religious coping has been shown to influence post-traumatic growth [33]. People who experience PTG tend to seek religious experience and prioritize their involvement in spiritual growth [17]. Research [34] proved that religious coping and social support had a positive effect on PTG. Religious coping is carried out in spiritual ritual activities both individually (for example, individual prayer) and collectively (for example, praying in groups or colossal). The PTG mechanism is largely determined by a personal relationship with God or with other greater forces that can give them hope in a crisis. Gerber et.al. (2011) mentions that religious life can help reduce anxiety, anxiety and tension [33]. Including those who have experienced the tsunami and conflict in Aceh [35]. They rely on the teachings of Islam, that everything is given to God. The trials of life as a sign of Allah love him and increase the level of faith (QS al- Baqarah 2/214).

Joseph's research [36], Bonanno \& Westpal [37] and Bensimon [38] found that resilience is a variable to overcome trauma and overcome feelings of loss. In the process of achieving PTG, reliability has significantly increased PTG. While Tsai et.al. [39] found that the PTG experience of veterans in the USA was strongly influenced by social support, religiosity and purpose in life. Research by Tedeschi and Calhoun [30], Rahmah [25] and Anantasari [38] mentions that social support is a predictor of positive change after a traumatic event that has a significant effect on PTG.

Based on the theoretical discourse mention above, this article discuse further the influence of positive religious coping, resilience and social support on posttraumatic growth of the jemaat Ahmadiyya.

\section{Theoritical Framework}

\section{Posttraumatic Growth}


As part of positive psychology studies since the 1990s, PTG has been widely researched by Linley \& Joseph [40], Joseph [41], Thabet [42], etc. Tesdechi \& Calhoun [30] defines PTG as a positive change that results from one's struggle in facing a stressful life crisis, which is characterized by an appreciation of life, relationships with others, personal strength, new possibilities and spiritual change.

Factors that influence PTG include religious coping [35], coping strategies [43], and coping methods [40], resilience [30], [44], social support, personality characteristics [30], [43], religiosity and spirituality [33], [45]

This study uses The Posttraumatic Growth Inventory (PTGI) from Tadeschi \& Calhoun [46] with a 21-item scale with five dimensions of PTG: appreciation of life, relating to others, personal strength, new possibilities and spiritual change.

\section{Positive Religious Coping}

In addition to Pargament, Koenig and Perez [33], Pargament et.al. [47] mentioned that positive religious coping is a strategy for understanding and overcoming sources of stress by using religious functions and closeness to God. There are five basic functions of religion according to Pargement, Koenig \& Perez [33].

This study uses the RCOPE Brief by Pargament et.al. [47] based on five religious functions: meaning (benevolent religious reappraisal), control (collaborative religious coping), comfort (seeking spiritual support, spiritual connection), intimacy (support seeking from clergy or members, religious helping), life transformation (religious forgiving).

\section{Resiliency}

Thabet [29], Smith [48], Kobylarczyk \& Bulik [49], Tugade \& Fredrickson [50] and Zautra [51], and Grotberg [52] say that a person, group or community has the capacity in dealing with, overcoming, reinforced by and even transformed from the experience of facing difficulties, both because of man-made or natural disasters, called resilience. This is a universal capacity which can prevent, minimize or overcome the effects of difficulties. Resilience contributes to mental health when they experience difficult situations that come from: external supports (i have), inner strength (i am), and interpersonal and problem- solving skills (i can). This study uses the Grotberg [52] International Resilience Research Project (IRRP) measurement tool.

\section{Social Support}

Social support referring to perceived comfort, attention, self-esteem, or helping one receives from another person or group in human interaction where social, emotional, instrumental and recreational resources are exchanged [53], [54] . Linley \& Joseph [40] and Rzeszutek [55] mention social support as having an effect on PTG. Tadeschi \& Calhoun [56] say that the 
source of social support comes from spouses, family and friends. It becomes an important moderation for mental health because of its potential to be able to protect people from a variety of physical and psychological disorders. According to Schwarzer \& Sculz [57] there are four dimensions of social support: perceived emotional support, perceived instrumental support, need for support, and support seeking which are the basis for compiling the Berlin Social Support Scales (BSSS), a measure developed by Schwarzer \& Sculz [57].

\section{Research Method}

This article discuses the effect of positive religious coping, resilience and social support on the PTG of the 200 jemaat Ahmadiyah. They were victims of the attack in 2005 residing in the Cianjur area selected by non-probability sampling with purposive sampling technique.

Data collection techniques used four Likert model questionnaires with four response categories: "Strongly Agree", "Agree", "Disagree" and "Strongly Disagree". Statements are prepared in a positive (favorable) and (unfavorable). The validity of the measuring instrument using Lisrel 8.70. The research hypothesis was tested by multiple regression analysis. Due to testing with statistical analysis, the hypothesis is converted to a null hypothesis.

From the multiple regression analysis it is obtained information that $\mathrm{R} 2$ shows the proportion of variance (percentage of variance) and the dependent variable that can be explained by the independent variable. Hypothesis testing regarding the significance of the impact or effect of all independent variables on the dependent variable. Hypothesis testing regarding the significance or absence of each regression coefficient. Significant coefficient shows the significant influence of the relevant variable in question. R2 change which shows the amount of the contribution or contribution of each independent variable to the dependent variable. Hypothesis testing regarding the significance or absence of each contribution of each independent variable to the dependent variable.

\section{Research Data Results And Analysis}

The data analysed in this study are pure scores (t-scores) which are the result of the conversion process from raw scores. To get a statistical description, only valid and positive items are counted, so a factor score is obtained. To avoid measurement error bias, factor scores are only calculated as true scores (t-scores) on each scale, especially factor scores that are positively and significantly charged. Based on the $t$-score, the default value is analyzed in the correlation and regression hypothesis test. In the results of this descriptive analysis will be presented the minimum, maximum, mean and standard deviation of variables as well as the categorization of high and low scores of the research variables.

The categorization of research variable scores aimed at placing individuals into separate groups in stages according to a continuum based on the measured attributes. Before categorizing, the norm of the score is determined using the mean and standard deviation in the previous table and applies to all variables. Next will be explained by the acquisition of 
a percentage value for each variable and the dimensions of the of the variable in which each variable will be categorized as low and high.

\begin{tabular}{|c|c|c|c|}
\hline $\mathrm{Nu}$ & Categorization & $\begin{array}{c}\text { Freque } \\
\text { ncy }\end{array}$ & $\begin{array}{l}\text { Perce } \\
\text { ntage }\end{array}$ \\
\hline 1 & Low & 114 & $57 \%$ \\
\hline \multirow[t]{2}{*}{2} & High & 86 & $43 \%$ \\
\hline & Total & 200 & $100 \%$ \\
\hline
\end{tabular}

Table 1 explains that the percentage of posttraumatic growth in the jemaat Ahmadiyya victims of assault by $57 \%$ in the low category and $43 \%$ in the high category.

\begin{tabular}{|c|c|c|c|c|}
\hline $\begin{array}{l}N \\
\mathrm{u}\end{array}$ & Aspect & $\begin{array}{l}\text { Categoriz } \\
\text { ation }\end{array}$ & $\begin{array}{l}\text { Frequ } \\
\text { ency }\end{array}$ & $\begin{array}{l}\text { Perce } \\
\text { ntage }\end{array}$ \\
\hline \multirow[t]{2}{*}{1} & Meaning & Low & 99 & $49,5 \%$ \\
\hline & & High & 101 & $50,5 \%$ \\
\hline \multirow[t]{2}{*}{2} & Control & Low & 115 & $57,5 \%$ \\
\hline & & High & 85 & $42,5 \%$ \\
\hline \multirow[t]{2}{*}{3} & Comfort & Low & 105 & $52,5 \%$ \\
\hline & & High & 95 & $47,5 \%$ \\
\hline \multirow[t]{2}{*}{4} & Intimacy & Low & 102 & $51 \%$ \\
\hline & & High & 98 & $49 \%$ \\
\hline \multirow[t]{2}{*}{5} & Life & Low & 94 & $47 \%$ \\
\hline & transform & High & 106 & $53 \%$ \\
\hline
\end{tabular}

Table 2 describes the respondents had a low benevolent religious reappraisal score of $45.5 \%$ and $54.5 \%$ were in the high category. In the collaborative religious coping variable in the low category by $51.5 \%$ and $48.5 \%$ were in the high category. In the variable seeking spiritual support in the low category by $49 \%$ and $51 \%$ in the high category. In the spiritual connection variable in the low category by $57.5 \%$ and $42.5 \%$ were in the high category. In the variable support seeking from clergy or members in the low category by $52.5 \%$ and $47.5 \%$ in the high category. In the religious helping variable in the low category by $47 \%$ and $53 \%$ were in the high category. In the religious forgiving variable in the low category by $48 \%$ and $52 \%$ in the high category.

Table 3: describes the external support category of $55.5 \%$ high category. In the variable in the low and $40 \%$ in the high interpersonal-problem

\begin{tabular}{lllll}
\multicolumn{4}{c}{ Table 3 Resilience Score Category } \\
\hline $\mathbf{N}$ & Aspect & Cetegorization & Frequency & Percentage \\
$\mathbf{u}$ & & & & \\
\hline 1 & External & Low & 111 & $55,5 \%$ \\
& Support & High & 89 & $44,5 \%$ \\
2 & Inner & Low & 120 & $60 \%$ \\
& Strength & High & 80 & $40 \%$ \\
3 & Interperson & Low & 129 & $64,5 \%$ \\
& al-Problem & High & 71 & $35,5 \%$ \\
& Solving & & & \\
& Skills & & & \\
\hline
\end{tabular}

respondents have scores in the low and $44.5 \%$ are in the inner strength category by $60 \%$ category. In the solving skills 
variable in the low category by $64.5 \%$ and $35.5 \%$ were in the high category.

\begin{tabular}{|c|c|c|c|c|}
\hline $\mathrm{N}_{\mathrm{u}}$ & Aspect & $\begin{array}{l}\text { Cetego } \\
\text { ization }\end{array}$ & $\begin{array}{c}\text { Freque } \\
\text { ney }\end{array}$ & $\begin{array}{l}\text { Percent } \\
\text { ge }\end{array}$ \\
\hline \multirow[t]{2}{*}{1} & \multirow{2}{*}{$\begin{array}{l}\text { Perceived } \\
\text { emotional } \\
\text { support }\end{array}$} & Low & 101 & $50,5 \%$ \\
\hline & & High & 99 & $49,5 \%$ \\
\hline \multirow[t]{2}{*}{2} & Perceived & Low & 91 & $45,5 \%$ \\
\hline & $\begin{array}{l}\text { Instrumen } \\
\text { tal }\end{array}$ & High & 109 & $54,5 \%$ \\
\hline \multirow[t]{2}{*}{3} & support & Low & 107 & $53,5 \%$ \\
\hline & Need for & High & 93 & $46,5 \%$ \\
\hline \multirow[t]{2}{*}{4} & support & Low & 114 & $57 \%$ \\
\hline & $\begin{array}{l}\text { Support } \\
\text { seeking }\end{array}$ & High & 86 & $43 \%$ \\
\hline
\end{tabular}

Table 4: respondents have a score of perceived emotional support in the low category by $50.5 \%$ and $49.5 \%$ in the high category. In the variable perceived instrumental support in the low category by $45.5 \%$ and $54.5 \%$ in the high category. In the variable need for support in the low category of $53.5 \%$ and $46.5 \%$ in the high category. In the support seeking variable in the low category by $57 \%$ and $43 \%$ in the high category.

\section{Research hypothesis}

Research hypothesis testing with multiple analysis techniques using SPSS 17 software. In the regression there are 4 things that are seen: the amount of R Square to determine the percentage (\%) contribution of the dependent variable of the independent variable; does the overall independent variable significantly influence the dependent variable; see the significance of the regression coefficients of each independent variable, and see the magnitude of the contribution of each independent variable and dependent variable and see the significance.

Table 5 R Square

\begin{tabular}{|c|c|c|c|c|}
\hline \multirow[b]{2}{*}{ Model } & \multirow[b]{2}{*}{$\mathbf{R}$} & \multirow[b]{2}{*}{$\begin{array}{l}\text { R } \\
\text { Square }\end{array}$} & \multirow{2}{*}{$\begin{array}{l}\text { Adjudte } \\
\text { d R R } \\
\text { Square } \\
\end{array}$} & \multirow{2}{*}{$\begin{array}{l}\text { Std. } \\
\text { Erros of } \\
\text { the } \\
\text { Estimete }\end{array}$} \\
\hline & & & & \\
\hline 1. &, 776 &, 602 & .577 & 6,07556 \\
\hline
\end{tabular}

Table 5: explores that $R$ Square acquisition of 0.602 or $60.2 \%$. This means that $60.2 \%$ of PTG variations can be explained by all independent variables while the remaining $39.8 \%$ is influenced by other variables outside this research variable. Next analyze the impact of all independent variables on PTG with the F test:

\begin{tabular}{|c|c|c|c|c|c|c|}
\hline $\begin{array}{c}\text { Mode } \\
1 \\
\end{array}$ & & $\begin{array}{l}\text { Sum } f \\
\text { Squares } \\
\end{array}$ & DF & $\begin{array}{c}\text { Mean } \\
\text { Square }\end{array}$ & $\mathbf{F}$ & Sig. \\
\hline \multirow{4}{*}{1.} & Regressio & & & & & \\
\hline & $\mathrm{n}$ & 10445.310 & 12 & 870.442 & 23.581 & $.000^{2}$ \\
\hline & Residual & 6902.619 & 187 & 36.912 & & \\
\hline & Total & 17347.929 & 199 & & & \\
\hline
\end{tabular}


Table 6: the significance rate is $0,000(\mathrm{sig}<0.05)$. It means zero hypothesis is rejected. There is a significant influence of meaning, control, comfort, intimacy, life transformation, external supports, inner strength, interpersonal \& problem solving skills, perceived emotional support, perceived instrumental support, need for support and support seeking for posttraumatic growth in the jemaat Ahmadiyya. Next look at the regression coefficient for each independent variable. If the sig value $<0.05$, the regression coefficient is significant. Means that the independent variable has a significant impact on PTG.

\begin{tabular}{|c|c|c|c|c|c|c|}
\hline \multirow[t]{2}{*}{$\begin{array}{l}\text { Mo } \\
\text { del }\end{array}$} & & \multicolumn{2}{|c|}{$\begin{array}{l}\text { Unstandardize } \\
\text { d Coefficients }\end{array}$} & \multirow[t]{2}{*}{$\begin{array}{l}\text { Standar } \\
\text { dized } \\
\text { Coefficie } \\
\text { nts }\end{array}$} & \multirow[t]{2}{*}{ t } & \multirow{2}{*}{$\begin{array}{l}\mathrm{s} \\
\mathrm{i} \\
\mathrm{g} \\
\mathrm{y}\end{array}$} \\
\hline & & $\mathbf{B}$ & Std.Erro & & & \\
\hline & 'onstant) & 8,025 & 4,432 & & 1,811 &, 072 \\
\hline 1. & Meaning & , 116 & ,061 & ,118 & 1,898 & ,059 \\
\hline 2. & Contral &,- 102 & 079 & -100 & $-1,280$ &, 202 \\
\hline 3. & Comfort & ,039 & ,068 & ,039 &, 578 &, 564 \\
\hline 4. & Intimacy &, 342 & 079 &, 336 & 4,327 &, 000 \\
\hline 5. & 'ifetrans &,- 119 & ,079 &,- 115 & $-1,502$ & , 135 \\
\hline 6. & I have &,- 149 & ,061 &,- 151 & $-2,436$ &, 016 \\
\hline 7. & I am &, 565 & ,064 &, 539 & 8,783 &, 000 \\
\hline 8. & $I \mathrm{can}$ & ,054 & ,060 &, 050 & 901 &, 369 \\
\hline 9. & PES & .257 & ,060 &, 253 & 4,261 & , 000 \\
\hline 10. & PIS &,- 460 &, 074 &,- 441 & $-6,180$ &, 000 \\
\hline 11. & NFS & ,059 &, 083 & ,055 & ,715 & ,476 \\
\hline 12. & EKSUP & .237 & .070 & .232 & 3.364 & .001 \\
\hline
\end{tabular}

Note: $(*)=$ significant

Posttraumatic growth $=$

11,6 meaning - 102 control $+0,039$ comfort $+0,342$ intimacy* $-0,119$ life transformation 0,149 external supports (I have)* $+0,565$ inner strength (I am)* $+0,054$ interpersonal \& problem solving skills (I can) $+0,257$ perceived emotional support* $-0,460$ perceived instrumental support* $+0,059$ need for support $+0,237$ support seeking* In the table 7 it can be seen the intimacy, external supports, inner strength, perceived emotional support, perceived instrumental support and seeking support significantly influence PTG. Column sig. in Table 4.12 , if $\mathrm{p}<0.05$, the resulting regression coefficient has a significant effect on PTG and vice versa. The regression coefficient values for each independent variable are: (1) meaning is positively influential but not significant to PTG; (2) control negatively influences but is not significant to PTG; (3) intimacy has a significant positive effect on PTG; (4) life transformation negatively influences but not significantly to PTG; (5) external supports (i have) negatively significantly influence posttraumatic growth; (6) inner strength (i am) has a significant positive effect on PTG; (7) interpersonal \& problem solving skills (i can) negatively affect but not significantly to PTG; (8) positive emotional support has a significant 
effect on PTG; (9) perceived instrumental support has a significant negative effect on PTG; (10) need for support has a positive but not significant effect on PTG; and (11) support seeking positively has a significant effect on PTG.

Table 8 below explain there are seven independent variables consisting of inner strength, intimacy, perceived instrumental support, comfort, support seeking, life transformation and need for support make a significant contribution to PTG. It can also be seen which ones contribute the most to PTG. Can be seen by looking at the value of R2 change, if the greater the more donations are given to the dependent variable. It is known that the order of independent variables gives the largest to the smallest contribution. Successively: inner strength $(\mathrm{i}$ am) with R2 change $=35.6 \%$; intimacy with R2 change $=0.53 \%$; perceived instrumental support with R2 change $=0.52 \%$; comfort with R2 change $=0.32 \%$; support seeking with R2 change $=0.32 \%$; life transformation with R2 change $=0.24 \%$; need for support with R2 change $=0.09 \%$.

Table 8 proportion of variance for each

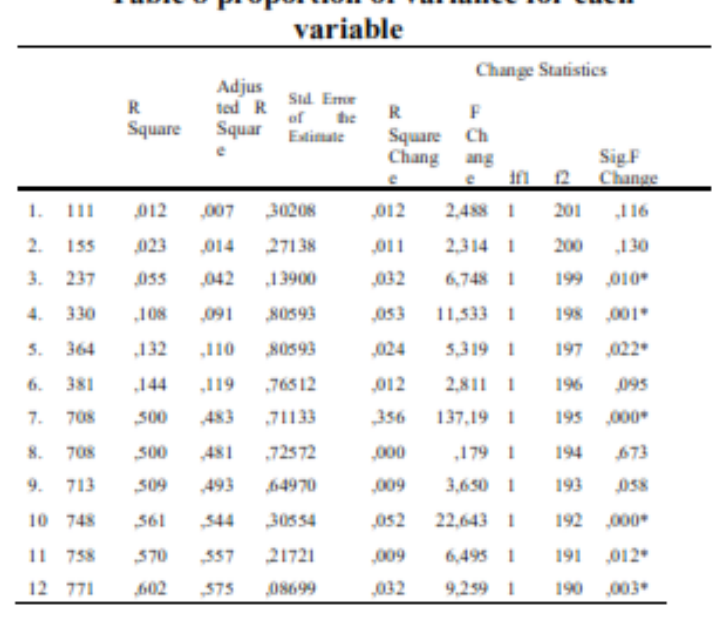

\section{Noted:}

$\begin{array}{ll}\mathbf{X 1} & \text { : Meaning } \\ \mathbf{X 2} & \text { : Control } \\ \mathbf{X 3} & \text { : Comfort } \\ \mathbf{X 4} & \text { : Intimacy } \\ \mathbf{X 5} & \text { : Life transformation } \\ \mathbf{X 6} & \text { : External supports }(i \text { have) } \\ \mathbf{X 7} & \text { : Inner Strength }(\text { i am) } \\ \mathbf{X 8} & \text { : Interpesonal \& problem solving skills }(i \text { can }) \\ \mathbf{X 9} & \text { : Perceived emotional support } \\ \mathbf{X 1 0} & \text { : Perceived instrumental support } \\ \mathbf{X 1 1} & \text { : Need for support } \\ \mathbf{X 1 2} & \text { : Support seeking }\end{array}$




\section{Conclussion}

Based on the results of the analysis and hypothesis testing it was concluded that the hypothesis "there is a significant influence of positive religious coping, resilience and social support for PTG on jemaat Ahmadiyya who are victims of the attack (H0)" was rejected. There are six significant dimensions of PTG, namely intimacy, external supports (i have), inner strength (i), perceived emotional support, perceived instrumental support and support seeking. Six minor hypotheses were accepted: intimacy, external supports (i have), inner strength ( $\mathrm{i}$ am), perceived emotional support, perceived instrumental support and support seeking. Based on the proportion of the total variance, all independent variables contributed $60.2 \%$ in the PTG variance.

Six dimensions that contributed significantly to PTG, among others, inner strength (i am) by instrumental support by $0.52 \%$, comfort by $0.32 \%$, support seeking of $0.30 \%$, life transformation of $0.24 \%$, need for support of $0.09 \%$.

\section{Discussion}

There is a significant positive influence on religious coping, resilience and social support for the PTG of the jemaat Ahmadiyya. The dimensions of intimacy, external supports (i have), inner strength ( $\mathrm{i}$ am), perceived emotional support, perceived instrumental support and Intimacy, which is one of the dimensions of positive religious coping, positively and significantly affects PTG. This is in line with the research of Park et.al. [33] and Pargament, Koenig \& Perez [58]. Positive religious coping is able to see the religious point of view and take lessons from any difficulties to develop personality, especially in people who experience negative events. This is also consistent with Mardiah \& Syahriati's [59] that victims of the Aceh conflict used intimacy to achieve PTG. People who are traumatized get closer to God and feel closer to others.

After experiencing the attack, the jemaat Ahmadiyya draws closer to Allah SWT through worshiping and asking for direct protection from Him. The jemaat Ahmadiyya also got closer to each other after the attack. When the jemaat Ahmadiyya evacuated, they strengthened each other. This phenomenon is in line with the results of this study, the dimensions of perceived emotional support in a positive and significant effect on PTG. The dimensions of perceived emotional support belong to the dimension of the social support variable. This is consistent with the research of Tadeschi \& Calhoun [30], that people who experience a traumatic event need social support. The jemaat Ahmadiyya of the victims of the attack needs emotional support such as giving love, love, empathy and care so that the process of maximizing the PTG process. After the attack emotional support was very influential for the jemaat Ahmadiyya, to restore psychological conditions and heal the trauma that had been experienced.

This study shows that the external dimensions of supports negatively significantly influence PTG. The higher external support obtained from the family, the lower PTG. This is because after the attack many jemaat Ahmadiyya did not have the support of their fellow families because they had differences in their faith with the Ahmadiyya and there were several jemaat Ahmadiyya who decided to leave the Ahmadiyya so that within one family there was a conflict between having to survive or leave. Another thing that also makes the external dimension of support from the family have a significant but negative effect. 
Therefore, congregants who experience posttraumatic growth do not depend solely on support from the family, but support from outside, such as fellow Ahmadiyya followers.

Inner strength which is one dimension of resilience positively affects PTG. In line with Rahayu's [60] which found that adolescent victims of sexual violence can rise from trauma, because it has strong personal characteristics. Tadeschi \& Calhoun [30]found that people who experience a traumatic event are able to develop more personal power than before. Personal strength is also one aspect that shapes the subject's ability to deal with trauma and change the trauma experience to positive change (PTG).

The dimension of perceived instrumental support has a significant influence with a negative direction. This means that the higher the perceived instrumental support the lower the PTG. This is because the jemaat Ahmadiyya has no effect when given assistance in the form of money, objects and so forth. And the majority grew out of trauma because of the desire to work hard and improve economic conditions more than ever before. For example, when all the merchandise of an jemaat Ahmadiyya who happened to be a shop owner was taken away from the attack, the congregation then tried even harder to develop its shop.

Support seeking which is also included in one of the dimensions of social support also affects PTG. This is consistent with the research of Tadeschi \& Calhoun [30]that people who experience PTG can also grow with the help of others as well. Looking for help after experiencing a period of crisis in life is very important, this is because humans are not able to live alone and need help from others. Experienced firsthand the events of the attack such as seeing his house burned, destroyed, listening to the sound of screams.

The dimensions of meaning, control, comfort, life transformation, interpersonal \& problem solving skills (i can) and need for support have no significant effect on PTG because the attack on the jemaat Ahmadiyya had occurred around 14 years ago and enabled there are other dimensions that might affect the PTG process for the jemaat Ahmadiyya. The effect not affected due to the measurement tools used in this study are used in different populations.

\section{References}

[1] Allport, Gordon W., (May 1927), Concepts of Traits and Personality. Psychological Bulletin, 24 (5), 284-293

[2] Rogers, Carl R., (1961), On Becoming a Person: A Therapist's View Psychotherapy. Boston: Houghton Mifflin Company

[3] Maslow, Abraham H., (1954), Motivation and Personality. New York: Harper

[4] Frankl, Viktor E., (1992), Man's Search forMeaning. Boston: Beacon Press

[5] Edwards, Jenny, et. al., (2016), Fundamental Facts About Mental Health 2016. Mental Health Foundation: London

[6] Halgin, Richar P., (2009), Abnormal Psychology: Clinical Perspectives on Psychological Disorders. New York: McGraw-Hill

[7] Daradjat, Zakiah, Kesehatan Mental. Jakarta: Gunung Agung, 1975

[8] Hamid, Abdul. (2017). Agama dan kesehatan mental dalam perspektif psikologi agama. Healthy Tadulako Journal, 3 (1). 1-84.

[9] ILO. (2009). Law on Health (Law No. 36/2009). International Labour Organization.

[10] Wilber, Ken; Patten, Terry; Leonard, Adam; Morelli, Marco, (2008), Integral Life Practice: A 21stCentury Blueprint for Physical Health, Emotional Balance, Mental Clarity, and Spiritual Awakening. New York: Integral Books 
[11] Loewenthal, K. (2007). Religion, culture and mental health. Cambridge University Press.

[12] J. J. López-Ibor. (2005). What is a Disaster? In J. J. López-Ibor, G. Christodoulou, M. Maj, N. Sartorius, \& A. Okasha (Eds.), Disasters and mental health (p. 1-12). John Wiley \& Sons Lt.

[13] Ursano, R. J.; Fullerton, C. S., Norwood A. E., (ed), (2003), Terrorism \& Disaster: Individual \& Community Mental Health Interventions. Cambridge: Cambridge University Press

[14] Mills, China, Decolonizing Global Mental Health: The Psychiatrization of the Majority World. Routledge: Routledge, 2014

[15] Kase, Larina; Ledley, Deborah Roth; Weiner, Irving B., (2007), Wiley Concise Guides to Mental Health: Anxiety Disorders. England: Wiley

[16] Stein, D. J., F., Matthew, and B., Carlos, (ed.), (2011), Post-traumatic Stress Disorder. Routledge: Wiley-Blackwell

[17] Tedeschi, R.G., Calhoun, L.G. (1996). PTG inventory: measuring the positive legacy of trauma. Journal of Traumatic Stress, 9 (3)

[18] Syafaat, Ibnu (2011). Amir ahmadiyah: bedanya ahmadiyah dengan islam pada imam mahdi. Download at 28 June 201922.33 from https://m.hidayatullah.com/berita/nasio nal/read/2011/02/17/46575/amir-ahmadiyah-bedanyaahmadiyah-dengan-islam-pada-imam-mahdi.html.

[19] Bonasir, Rohmatin (2018). Kenapa ahmadiyah dianggap bukan islam: fakta dan kontroversinya, Diakses pada tanggal 28 Juni 2019 pukul 23.00. Diunduh dari https://www.bbc.com/indonesia/indone sia-42642858.

[20] Wulandari, N. (2013). Warga Ahmadiyah Tasikmalaya Trauma. https://kbr.id/berita/052013/warga ahmadiyah tasikmalaya trauma/54227.html

[21] Loeber, R., Farrington, D.P., StouthamerLoeber, M., and Van Kammen, W.B. 1998. Antisocial Behavior and Mental Health Problems: Explanatory Factors in Childhood and Adolescence. Mahwah, NJ: Lawrence Erlbaum.

[22] Rakhmatullah (2014). Ini akibat intoleransi agama di Indonesia. Diakses pada 18 November 2018 pukul 20.20. Diunduh dari https://nasional.sindonews.com/read/940714/15/ini-akibattindakan- intoleransi-agama-di-indonesia-1419241075.

[23] Goulston, Mark, (2007), Post-Traumatic Stress Disorder: For Dummies. Indiana: Wiley Publishing

[24] Stocker, Susan Rau, (2010), Many Faces of PTSD: Does Post Traumatic Stress Disorder Have a Grip On Your Life?. Uniontown, USA: Holy Macro Books

[25] Rahmah, Siti. (2017). Post traumatic growth pada remaja korban konflik Aceh. Psikoislamedia jurnal psikologi, 2 (2).

[26] Roberts, Cheryl A., (2011), Coping with Post- Traumatic Stress Disorder: A Guide for Families. London: McFarland and Company, Inc., Publishers

[27] Scott, Michael J., Stradling, Stephen G., (2006), Counselling for Post-traumatic Stress Disorder. New Delhi: Sage Publication.

[28] Schiraldi, Glenn, (2009), The Post-Traumatic Stress Disorder Sourcebook: A Guide to Healing, Recovery, and Growth $\sim$ 2nd Edition. Toronto: McGrawHill

[29] Thabet, Abdel Aziz Mousa. (2017). Trauma, mental health, coping, resilience, and PTG-Palestinian experience. JOJ Nurse Health Care, 2 (2).

[30] Tedeschi, R.G., Calhoun, L.G (2004).Posttraumatic growth: conceptual foundations and empirical evidence. Psychological Inquiry. 15 (1), 1-18.

[31] Laufer \& Solomon (2011). The role of religious orientations in youth's posttraumatic symtoms after exposure to terror. Journal of Religion and Health, 50 (3)

[32] Linley, P.A., Joseph, S. (2004). Positive change following trauma and adversity: a review, Journal of Traumatic Stress, 17 (1). 
[33] Gerber, M.M., Boals, Adriel., Schuettler, Darnell. (2011). The unique contributions of positive and negative religious coping to posttraumatic growth and ptsd. Journal of Religion and Spiritual, 3 (4). 298-307.

[34] García, F., Páez-Rovira, D., Zurtia, G., Martel, H., \& Reyes, A. (2014). Religious Coping, Social Support and Subjective Severity as Predictors of Posttraumatic Growth in People Affected by the Earthquake in Chile on 27/2/2010. Religions, 5(4), 1132-1145.

[35] Mardiah, A. \& Syahriati, Elida. (2015). Can religious coping predict posttraumatic growth. Journal of Education in Muslim Society, 2 (1), 61-69. Retrieved from http://journal.uinjkt.ac.id/index.php/tar biya.

[36] Westpal, M., Bonanno, G.A. (2007). Posttraumatic growth and resilience to trauma: different sides of the same coin or different coins. Journal of Applied Psychology. 56 (3), 417-427.

[37] Bensimon, M. (2012). Elaboration on the association between trauma, PTSD and posttraumatic growth: the role of trait resilience. Journal of Personality and Individual Differences. 52 (7), $782-787$.

[38] Anantasari, M.L. (2011). Peran dukungan sosial terhadap pertumbuhan pascatrauma: studi metaanalisis. Jurnal Psikologi, 6 (1), 365-382.

[39] Tsai, J., El-Gabalawy, R., Sledge, W., Southwick, S., \& Pietrzak, R. (2015). Post-traumatic Growth Among Veterans in the USA: Results from the National Health and Resilience in Veterans Study. Psychological Medicine, 45, 165-179.

[40] Linley, P. A., \& Joseph, S. (2004). Positive change following trauma and adversity: A review. Journal of Traumatic Stress, 17(1), 11-21.

[41] Joseph, S. (2009). Growth following adversity: Positive psychological perspectives on posttraumatic stress. Psychological Topics, $18,335-344$.

[42] Thabet, A.A.M. (2017). Trauma, Mental Health, Coping, Resilience, and Post Traumatic Growth (PG)-Palestinian Experience. JOJ Nurse Health Care. 2(2)

[43] Prati, G. \& Pietrantoni, L. (2009). Optimism, social support, and coping strategies as factors contributing to posttraumatic growth: a meta-analysis.

[44] Schmidt-Ehmcke (2008). The relation between posttraumatic growth and resilience in the south. A research report submitted in partial fulfilment of the requirements for the degree of Masters in Clinical Psychology in the Faculty of Humanities, University of the Witwatersrand.

[45] Calhoun, L.G., Cann, A., Tedeschi, R.G., \& McMillan, Jamie. (2000). A correlational test of the relationship between posttraumatic growth, religion, and cognitive processing. Journal of Traumatic Stress, 13 (3).

[46] Tedeschi, R. G., \& Calhoun, L. G. (1996). The posttraumatic growth inventory: Measuring the positive legacy of trauma. Journal of Traumatic Stress, 9, 455-471.

[47] Pargament, K.I., Feuilleu, Margaret., \& Burdzy, Donna. (2011). The brief rcope: current psychometric status of a short measure of religious coping. Journal of Religions, 2, 51-76.

[48] Smith, T.S. (2018). Paradoxes of Resilience: A Review of the World Disasters Report 2016. Development and Change. International Institute of Social Studies. 49 (2): 662-677

[49] Ogińska-Bulik, N., \& Kobylarczyk, M. (2015). Resiliency and social support as factors promoting the process of resilience in adolescents-Wards of children's homes. Health Psychology Report, 3(3), 210-219.

[50] Tugade, M. M., \& Fredrickson, B. L. (2004). Resilient Individuals Use Positive Emotions to Bounce Back From Negative Emotional Experiences. Journal of Personality and Social Psychology, 86(2), 320-333. 
[51] Mahdi, Prihadi \& Hasyim (2014). Posttraumatic growth and resilience after a prolonged war: a study in Baghdad, Iraq. International Journal of Evaluation and Research in Education (IJERE), 3 (3), 197-204.

[52] Grotberg E.H. (2001). Resilience programs for children in disaster. Ambulatory child health, (7), 75-83.

[53] Boyle, Anne et.al. (1991). Personality hardiness, ways of coping, social support and burnout in critical care nurses. Journal of Advanced Nursing, 16 (7), 850-857.

[54] Marhamah, F. \& Hamzah, H.B. (2016). The relationship between social support and academic stress among first year students at syiah kuala university. Jurnal Psikoislamidea, 1 (1).

[55] Rzeszutek et.al. (2017). Social support, stress coping strategies, resilience and posttraumatic growth in a polish sample of HIV-infected individuals: results of a 1 year longitudinal study. Journal of Behavioral MedicineI. 40 (6), 942-954.

[56] Schwarzer \& Knoll (2007). Functional roles of social support within the stress and coping process: a theoretical and empirical overview. International Journal of Psychology. 42 (4), 243-252.

[57] Schwarzer \& Schulz (2000). Social support in coping with illness: the berlin social support scales (BSSS).

[58] Park, C.L., et.al. (2016). Positive and negative religious/spiritual coping and combat exposure as predictors of posttraumatic stress and perceived growth in Iraq and Afghanistan veterans. Psychology of Religion and Spiritual.

[59] Mardiah,A., Syahriati, E. (2015). Can Religious Coping Predict Posttraumatic Growth?. Proceedings of SOCIOINT15- $2^{\text {nd }}$, International Conference on Education, Social Sciences and Humanities.

[60] Rahayu, Diah (2016). Posttraumatic growth korban kekerasan pada anak dan remaja (studi di kota Samarinda). Journal of Psychology \& Humanity. Universitas Mulawarman Samarinda. 